\title{
CHROMATOGRAPHIC ANALYSIS OF SOME ANTIBIOTICS IN WATER AND SEDIMENT SAMPLES COLLECTED FROM THE ROMANIAN TISZA RIVER WATERSHED
}

\section{VIRGINIA COMAN ${ }^{\mathrm{a} *}$, SIMION BELDEAN-GALEA ${ }^{\mathrm{b}}$, FLORINA COPACIU $^{\mathrm{a}}$, MIHAELA VLASSA ${ }^{a}$, MIUŢA FILIPa}

\begin{abstract}
Antibiotics are natural or semi-synthetic compounds used for many decades in human, veterinary and plant medicine to prevent and/or to treat bacterial infections and also to promote productivity in animal farming. Traces of antibiotics are found in waste, surface and ground waters, the main source of water pollution being considered waste waters from the industrial production, hospitals, livestock farms, households and incompletely metabolized drugs. The uncontrolled input of antibiotics in surface waters can lead to some unexpected health effects and to an increased resistance to these drugs.

The aim of this work consists in the monitoring of six antibiotics (Ampicillin, Amoxicillin, Penicillin G, Ceftazidime, Tetracycline and Doxycycline) in river waters and sediment samples from the Romanian Tisza River Watershed.

Solid-phase extraction (SPE) on Oasis HLB Waters cartridges was used for the isolation of antibiotics from water matrices and ultrasound-assisted extraction (USAE) followed by SPE for the sediment samples. Then, the antibiotics were analysed by high-performance liquid chromatography coupled with diode array detector or mass spectrometer (HPLC-DAD/MS). The developed SPE/USAEHPLC-DAD/MS procedures were applied to monitor these antibiotics in river waters during thirteen months and to analyse them in some sediment samples. The obtained results showed the presence of Tetracycline, Doxycycline and Ceftazidime in the investigated samples.
\end{abstract}

Keywords: antibiotics, high-performance liquid chromatography, mass spectrometry, solid-phase extraction, ultrasound-assisted extraction, river waters, sediments

\footnotetext{
a Babeş-Bolyai University, Raluca Ripan Institute for Research in Chemistry, 30 Fântânele str., Cluj-Napoca, Romania

b Babeş-Bolyai University, Faculty of Environmental Science and Engineering, 30 Fântânele str., RO-400294, Cluj-Napoca, Romania

*Corresponding author: virginia.coman@ubbcluj.ro
} 


\section{INTRODUCTION}

Antibiotics are natural or semi-synthetic compounds with antibacterial, antifungal or antiparasitical activity [1] used for preventing and treating human and animal diseases, different plant infections and also for advancing growth in livestock farms [2]. The amount of antibiotics released in the European Union environment might be approximately 15,000 tons/year. The main sources of antibiotic pollution come from the industrial production, hospitals, domestic use and their incomplete metabolism [3].

Due to the fact that antibiotics are not completely removed by the sewage treatment plants, they are released into the natural water courses [1] causing potential environmental risks and the extension of antibacterial resistance among the microorganisms [4].

Different studies showed that antibiotics are persistent and pseudopersistent contaminants $[5,6]$ causing toxicological impacts on the fauna of natural water bodies [1] including synergistic and antagonistic combination effects [7].

In the aquatic matrices, the concentrations of antibiotics have values of micrograms per liter in hospital effluents and municipal waste waters, nanograms per liter in surface waters, ground water and sea water [8,9], tens nanograms per grams in estuary and marine sediments $[10,11]$ and hundreds nanograms per grams in surface water sediments respectively [12, 13]. Consequently, to prevent the risks of environmental exposure, the monitoring of antibiotics that reach the environmental factors is recommended [14, 15].

Taking into consideration the low level of the antibiotic residues in the environmental matrices, the development of sensitive analytical methods for the extraction and the analysis of these compounds represents a major challenge. The most used methods for the extraction of antibiotics from water samples involve solid-phase extraction [6, 8, 9, 12, 13] and miniaturized liquidphase or solid-phase extraction [16-18] and from sediment samples, ultrasoundassisted extraction $[11,13,19]$.

For the analysis of antibiotics, liquid chromatography (LC) techniques coupled with ultraviolet/diode-array (UV/DAD) detector [9, 18], mass spectrometry (MS) detector $[9,20]$ or tandem MS/MS ones [5, 10-12, 20] were used. Good results have been also obtained by high-performance thin-layer chromatography [6] or capillary electrophoresis $[16,17]$ techniques.

The aim of this work consists in the monitoring of some classes of antibiotics (penicillins, tetracyclines, cephalosporins) widely used for the human and veterinary treatments in different river water and sediment samples collected from the Romanian Tisza River Watershed using solid-phase extraction (SPE) and ultrasound-assisted extraction (USAE) followed by liquid chromatography coupled with diode-array or mass spectrometry detector. 


\section{RESULTS AND DISCUSSION}

Two analytical procedures, based on solid-phase extraction followed by high-performance liquid chromatography with diode array detector, respectively mass spectrometer (SPE-HPLC-DAD and SPE-LC-MS), have been developed for the analysis of six antibiotics (Amoxicillin - AMOX, Ceftazidime - CFZ Ampicillin - AMP, Tetracycline - TET, Doxycycline - DOXY and Penicillin G PEN G) in river water samples collected from the three established monitoring points in the Romanian Tisza River Watershed. For the sediment samples, the ultrasound-assisted extraction was used for the isolation of the target compounds from the matrix followed by the SPE-HPLC-DAD procedure.

The HPLC separation tooks place in less then 12 minutes with very good resolution. For the DAD detection was necessary two wavelengths, $197 \mathrm{~nm}$ for penicillins (AMOX, AMP, PEN G) and $272 \mathrm{~nm}$ for tetracyclines (TET, DOXY) and ceftazidime (CFZ) (Figure 1).

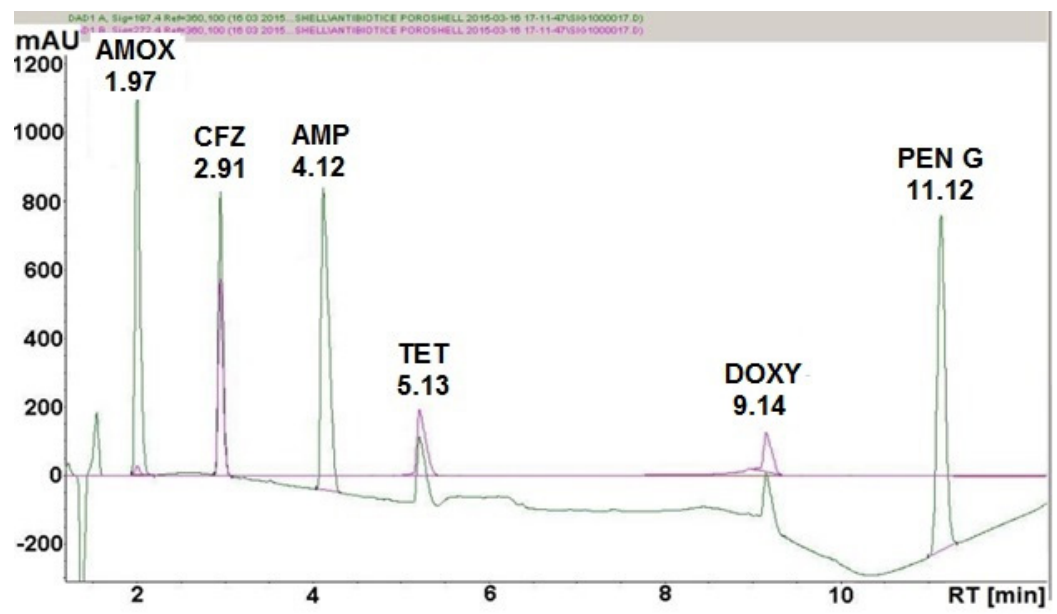

Figure 1. HPLC-DAD chromatogram of studied antibiotics

The developed HPLC-DAD method shows good linearity in the range of $5.21-166.7 \mu \mathrm{g} / \mathrm{mL}$, correlation coefficients ( $r$ ) exceeding 0.999 for all selected antibiotics, good repeatability (three replicates) measured for the $0.85 \mu \mathrm{g} / \mathrm{mL}$ concentration, low limit of detection (LOD) and limit of quantification (LOQ) in the range of $\mu \mathrm{g} / \mathrm{mL}$ (Table 1). The LOD and LOQ were calculated taking into account the slope of each calibration curve and the corresponding standard deviation. 
VIRGINIA COMAN, SIMION BELDEAN-GALEA, FLORINA COPACIU, MIHAELA VLASSA, MIUŢA FILIP

Table 1. Performances of the developed HPLC-DAD method

\begin{tabular}{|l|c|c|c|c|c|}
\hline Antibiotic & $\begin{array}{c}\text { Calibration curve } \\
\text { equation }\end{array}$ & $r$ & $\begin{array}{c}\text { LOD } \\
{[\mu \mathrm{g} / \mathrm{mL}]}\end{array}$ & $\begin{array}{c}\mathrm{LOQ} \\
{[\mu \mathrm{g} / \mathrm{mL}]}\end{array}$ & $\begin{array}{c}\text { Repeatability } \\
\text { RSD [\%] }\end{array}$ \\
\hline Amoxicillin & $\mathrm{Y}=50.42292 \mathrm{X}$ & 0.99968 & 0.61 & 1.86 & 5.43 \\
\hline Ceftazidime & $\mathrm{Y}=25.64547 \mathrm{X}$ & 0.99999 & 0.18 & 0.57 & 11.39 \\
\hline Ampicillin & $\mathrm{Y}=63.61580 \mathrm{X}$ & 0.99996 & 0.25 & 0.75 & 9.31 \\
\hline Tetracycline & $\mathrm{Y}=15.78180 \mathrm{X}$ & 0.99970 & 0.70 & 2.14 & 4.55 \\
\hline Doxycycline & $\mathrm{Y}=8.71137 \mathrm{X}$ & 0.99735 & 0.75 & 2.29 & 8.48 \\
\hline Penicillin G & $\mathrm{Y}=71.33844 \mathrm{X}$ & 0.99971 & 0.25 & 0.79 & 9.74 \\
\hline
\end{tabular}

For LC-MS analysis, the selected ion monitoring (SIM) mode was chosen in order to obtain a better sensitivity. In Figure 2, the chromatogram acquired in SIM mode is presented.

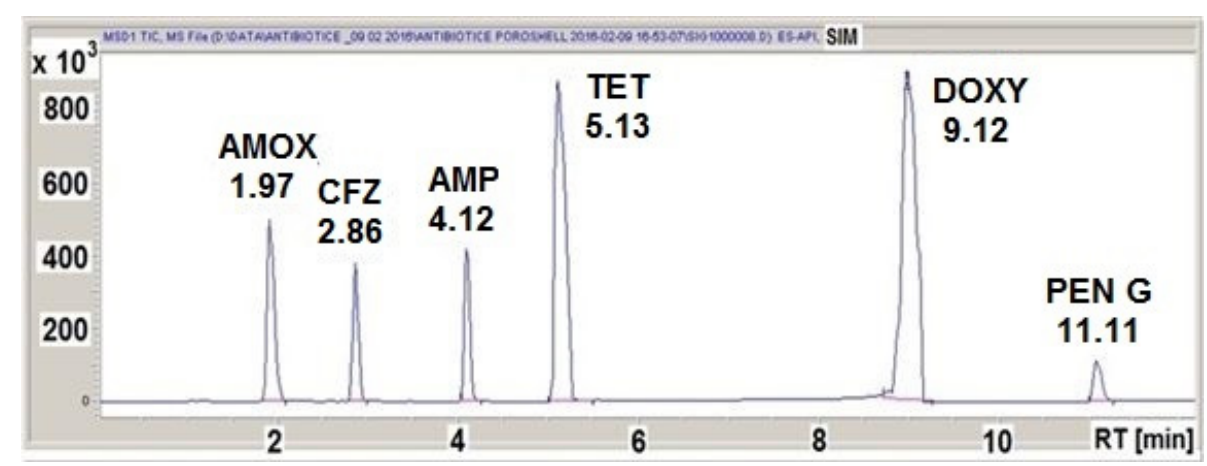

Figure 2. LC-ESI(+)-MS SIM chromatogram of studied antibiotics

The characteristic ion for each studied antibiotic was obtained by electrospray ionisation in positive mode $(\mathrm{ESI}(+))$. In Figure 3 are presented the mass spectra (scan mode ranging from 100 to 1000 uam) and the $\mathrm{m} / \mathrm{z}$ ions for the studied antibiotics. 

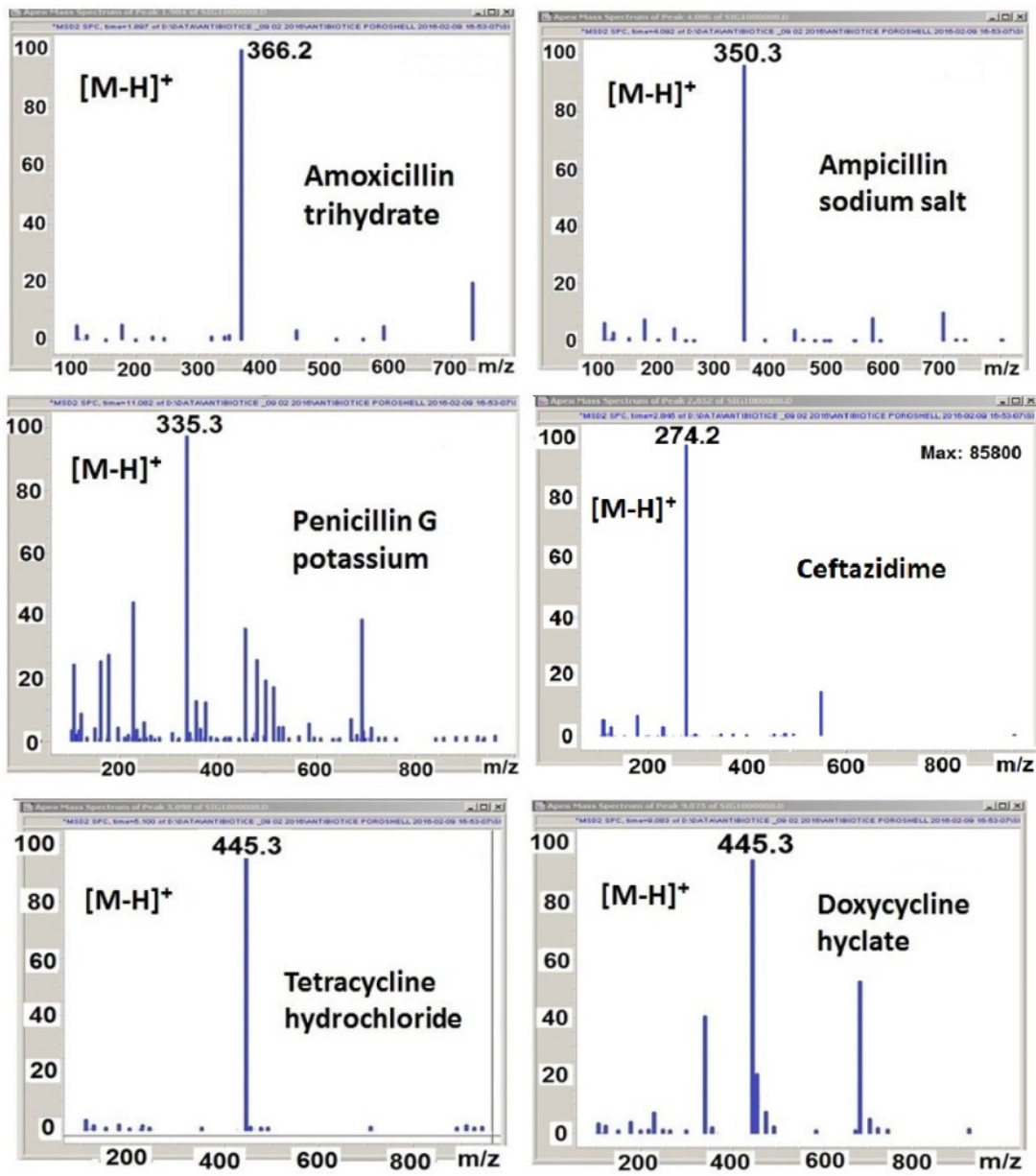

Figure 3. LC-ESI(+)-MS spectra of the studied antibiotics

The developed LC-ESI(+)-MS method shows good linearity in the range of $0.65-166.7 \mu \mathrm{g} / \mathrm{mL}$, correlation coefficients ( $r$ ) exceeding 0.99 for all selected antibiotics, good repeatability (three replicates) measured for the $0.85 \mu \mathrm{g} / \mathrm{mL}$ concentration, lower LOD and LOQ in the range of $\mathrm{ng} / \mathrm{mL}$ (Table 2).

Comparing the two developed LC methods, differing only by detectors, one can observe that these methods have the same linearity $(r>0.99)$, but the LC-ESI(+)-MS method is ten to hundred times more sensitive than the HPLC-DAD method (Table 3). 
Table 2. Performances of the LC-ESI(+)-MS method

\begin{tabular}{|l|l|c|c|c|c|}
\hline Antibiotic & \multicolumn{1}{|c|}{$\begin{array}{c}\text { Calibration curve } \\
\text { equation }\end{array}$} & $r$ & $\begin{array}{c}\mathrm{LOD} \\
{[\mu \mathrm{g} / \mathrm{mL}]}\end{array}$ & $\begin{array}{c}\mathrm{LOQ} \\
{[\mu \mathrm{g} / \mathrm{mL}]}\end{array}$ & $\begin{array}{c}\text { Repeatability } \\
\mathrm{RSD}[\%]\end{array}$ \\
\hline Amoxicillin & $\begin{array}{l}\mathrm{y}=17773.39271 \mathrm{x}+ \\
115572.17582\end{array}$ & 0.99383 & 0.0210 & 0.0636 & 4.79 \\
\hline Ceftazidime & $\begin{array}{l}y=11192.38273 x+ \\
59245.64014\end{array}$ & 0.99548 & 0.0196 & 0.0595 & 5.12 \\
\hline Ampicillin & $\begin{array}{l}y=11725.36209 x+ \\
39962.45772\end{array}$ & 0.99654 & 0.0157 & 0.0475 & 3.70 \\
\hline Tetracycline & $\begin{array}{l}y=45458.20719 x+ \\
38326.00614\end{array}$ & 0.99629 & 0.0178 & 0.0539 & 6.74 \\
\hline Doxycycline & $\begin{array}{l}y=67695.85510 x- \\
350854.03308\end{array}$ & 0.99608 & 0.0205 & 0.0622 & 6.00 \\
\hline Penicillin G & $\begin{array}{l}y=3007.03091 x+ \\
36758.78717\end{array}$ & 0.99084 & 0.0315 & 0.0955 & 3.11 \\
\hline
\end{tabular}

Table 3. Comparison of the performances of the developed methods:

HPLC-DAD versus LC-ESI(+)-MS

\begin{tabular}{|l|c|c|c|c|c|c|c|c|}
\hline \multirow{3}{*}{ Antibiotic } & \multicolumn{2}{|c|}{$\begin{array}{c}\text { RT } \\
{[\mathrm{min}]}\end{array}$} & \multicolumn{2}{c|}{$\begin{array}{c}\text { Correlation coefficient } \\
(\mathrm{r})\end{array}$} & \multicolumn{2}{c|}{$\begin{array}{c}\text { LOD } \\
{[\mu \mathrm{g} / \mathrm{mL}]}\end{array}$} & \multicolumn{2}{c|}{$\begin{array}{c}\text { LOQ } \\
{[\mu \mathrm{g} / \mathrm{mL}]}\end{array}$} \\
\cline { 2 - 10 } & DAD & MS & DAD & MS & DAD & MS & DAD & MS \\
\hline Amoxicillin & 1.97 & 1.97 & 0.99968 & 0.99383 & 0.61 & 0.021 & 1.86 & 0.064 \\
\hline Ceftazidime & 2.91 & 2.86 & 0.99999 & 0.99548 & 0.18 & 0.019 & 0.57 & 0.059 \\
\hline Ampicillin & 4.12 & 4.12 & 0.99996 & 0.99654 & 0.25 & 0.016 & 0.75 & 0.048 \\
\hline Tetracycline & 5.13 & 5.13 & 0.99970 & 0.99629 & 0.70 & 0.018 & 2.14 & 0.054 \\
\hline Doxycycline & 9.14 & 9.12 & 0.99735 & 0.99608 & 0.75 & 0.021 & 2.29 & 0.062 \\
\hline Penicillin G & 11.12 & 11.11 & 0.99971 & 0.99084 & 0.25 & 0.032 & 0.79 & 0.096 \\
\hline
\end{tabular}

However, LC-ESI(+)-MS method can be applied only for the analysis of samples of low complexity (water samples). In the case of complex (sediments) samples, HPLC-DAD method is recommended.

The accuracy has been tested only for Tetracycline and Doxycycline, considering that these antibiotics are the most prevalent in environmental samples. For this purpose, real river water samples were spiked with different amounts of Tetracycline and Doxycycline, and then extracted and analysed by SPE-LC-ESI(+)-MS procedure. The obtained results show good accuracy for both antibiotics, the recovery ranging between $95-100 \%$ (Table 4). 
CHROMATOGRAPHIC ANALYSIS OF SOME ANTIBIOTICS IN WATER AND SEDIMENT SAMPLES ...

Table 4. Accuracy of the SPE-LC-ESI(+)-MS procedure

\begin{tabular}{|c|c|c|c|c|c|}
\hline \multirow{2}{*}{ Antibiotic } & \multicolumn{3}{|c|}{ Amount $[\mu \mathrm{g} / \mathrm{mL}]$} & \multirow{2}{*}{$\begin{array}{c}\text { Recovery } \\
{[\%]}\end{array}$} & \multirow{2}{*}{$\begin{array}{c}\text { Mean recovery } \pm \\
\text { SD [\%] }\end{array}$} \\
\hline & Initial & Added & Found & & \\
\hline \multirow{9}{*}{ Tetracycline } & \multirow{3}{*}{0.58} & \multirow{3}{*}{0.46} & 1.08 & 103.84 & \multirow{3}{*}{$100.31 \pm 3.09$} \\
\hline & & & 1.02 & 98.07 & \\
\hline & & & 1.03 & 99.04 & \\
\hline & \multirow{3}{*}{0.58} & \multirow{3}{*}{0.58} & 1.11 & 95.68 & \multirow{3}{*}{$99.41 \pm 3.89$} \\
\hline & & & 1.20 & 103.44 & \\
\hline & & & 1.15 & 99.13 & \\
\hline & \multirow{3}{*}{0.58} & \multirow{3}{*}{0.69} & 1.30 & 102.36 & \multirow{3}{*}{$99.20 \pm 4.17$} \\
\hline & & & 1.20 & 94.48 & \\
\hline & & & 1.28 & 100.78 & \\
\hline \multirow{9}{*}{ Doxycycline } & \multirow{3}{*}{0.98} & \multirow{3}{*}{0.78} & 1.70 & 96.66 & \multirow{3}{*}{$98.50 \pm 2.34$} \\
\hline & & & 1.78 & 101.13 & \\
\hline & & & 1.72 & 97.72 & \\
\hline & \multirow{3}{*}{0.98} & \multirow{3}{*}{0.98} & 1.94 & 98.98 & \multirow{3}{*}{$97.26 \pm 1.57$} \\
\hline & & & 1.90 & 96.90 & \\
\hline & & & 1.88 & 95.91 & \\
\hline & \multirow{3}{*}{0.98} & \multirow{3}{*}{1.18} & 2.06 & 95.37 & \multirow{3}{*}{$95.21 \pm 2.09$} \\
\hline & & & 2.10 & 97.22 & \\
\hline & & & 2.01 & 93.05 & \\
\hline
\end{tabular}

The developed SPE-LC-ESI(+)-MS procedure was applied for monitoring of selected antibiotics in the Romanian Tisza River Watershed during 13 months from July 2014 to September 2015, thus covering all four seasons. Our results show the presence of some antibiotics in the river water samples. The most common antibiotics found are in concentrations of $\mu \mathrm{g} / \mathrm{L}$ as follows: Tetracycline in the range of $0.10-5.24$, Doxycycline in the range of $0.11-2.46$ and Ceftazidime in the range of $0.01-4.20 \mu \mathrm{g} / \mathrm{L}$ (Table 5). One can also observe that their concentrations are depending by the time and point of sampling. 
Table 5. Antibiotics found in Tisza River Watershed analysed by SPE-LC-ESI(+)-MS procedure

\begin{tabular}{|c|c|c|}
\hline Sampling date & Sampling point & Antibiotics found and their amounts $[\mu \mathrm{g} / \mathrm{L}]$ \\
\hline \multirow{3}{*}{$\begin{array}{l}\text { July } \\
2014\end{array}$} & Vișeu & Doxycycline (0.68), Ceftazidime (2.56) \\
\hline & Iza (2) & Tetracycline (1.24), Ceftazidime (3.43) \\
\hline & Tisza (3) & Doxycycline (2.40) \\
\hline \multirow{3}{*}{$\begin{array}{l}\text { August } \\
2014\end{array}$} & Vișeu (1) & Not detected \\
\hline & Iza (2) & Not detected \\
\hline & Tisza (3) & Ceftazidime (4.20) \\
\hline \multirow{3}{*}{$\begin{array}{l}\text { November } \\
2014\end{array}$} & Vișeu (1) & Doxycycline (0.11), Tetracycline (0.10) \\
\hline & Iza $\quad(2)$ & Tetracycline (2.56), Ceftazidime (0.01) \\
\hline & Tisza $(3)$ & Tetracycline $(0.82)$ \\
\hline \multirow{3}{*}{$\begin{array}{l}\text { December } \\
2014\end{array}$} & Vișeu (1) & Tetracycline $(0.11)$ \\
\hline & Iza (2) & Tetracycline $(0.56)$ \\
\hline & Tisza (3) & Tetracycline $(0.13)$ \\
\hline \multirow{3}{*}{$\begin{array}{l}\text { January } \\
2015\end{array}$} & Vișeu (1) & Tetracycline (3.96) \\
\hline & Iza $\quad(2)$ & Tetracycline (1.24), Doxycycline $(0.23)$ \\
\hline & Tisza (3) & Tetracycline (2.07) \\
\hline \multirow{3}{*}{$\begin{array}{l}\text { February } \\
2015\end{array}$} & Vișeu (1) & Tetracycline (2.65) \\
\hline & Iza $\quad(2)$ & Tetracycline (1.42), Doxycycline (0.19) \\
\hline & Tisza $(3)$ & Tetracycline (2.32) \\
\hline \multirow{3}{*}{$\begin{array}{l}\text { March } \\
2015\end{array}$} & Vișeu (1) & Not detected \\
\hline & Iza $\quad(2)$ & Not detected \\
\hline & Tisza (3) & $\begin{array}{l}\text { Tetracycline (3.07), Doxycycline (2.16), } \\
\text { Ceftazidime (4.15) }\end{array}$ \\
\hline \multirow{3}{*}{$\begin{array}{l}\text { April } \\
2015\end{array}$} & Vișeu (1) & Ceftazidime (4.19), Penicillin G (3.41) \\
\hline & Iza $\quad(2)$ & Not detected \\
\hline & Tisza (3) & Not detected \\
\hline \multirow{3}{*}{$\begin{array}{l}\text { May } \\
2015\end{array}$} & Vișeu (1) & Not detected \\
\hline & Iza $\quad(2)$ & Tetracycline (5.24) \\
\hline & Tisza (3) & Penicillin G (4.67) \\
\hline \multirow{3}{*}{$\begin{array}{l}\text { June } \\
2015\end{array}$} & Vișeu (1) & Tetracycline (1.47), Doxycycline (0.78) \\
\hline & Iza $\quad(2)$ & Tetracycline (3.32), Ceftazidime (0.06) \\
\hline & Tisza (3) & $\begin{array}{l}\text { Tetracycline }(1.83) \text {, Doxycycline }(0.26) \\
\text { Ceftazidime }(0.17)\end{array}$ \\
\hline \multirow{3}{*}{$\begin{array}{l}\text { July } \\
2015\end{array}$} & Vișeu (1) & Tetracycline (1.01), Doxycycline (0.94) \\
\hline & Iza & Tetracycline $(0.03)$ \\
\hline & Tisza (3) & Tetracycline (0.69), Doxycycline (0.19) \\
\hline \multirow{3}{*}{$\begin{array}{l}\text { August } \\
2015\end{array}$} & Vișeu (1) & Tetracycline $(0.49)$ \\
\hline & Iza & Tetracycline $(0.60)$ \\
\hline & Tisza (3) & Tetracycline $(0.52)$ \\
\hline \multirow{3}{*}{$\begin{array}{l}\text { September } \\
2015\end{array}$} & Vișeu (1) & Tetracycline (0.78), Doxycycline (0.36) \\
\hline & Iza $\quad(2)$ & Tetracycline (0.47), Doxycycline (2.46) \\
\hline & Tisza (3) & $\begin{array}{l}\text { Tetracycline }(1.88) \text {, Doxycycline }(0.26) \\
\text { Ceftazidime }(0.15)\end{array}$ \\
\hline
\end{tabular}


A SIM chromatogram of an extract of a real river water sample is presented in Figure 4 where one can be observed the presence of Tetracycline and Doxycycline.

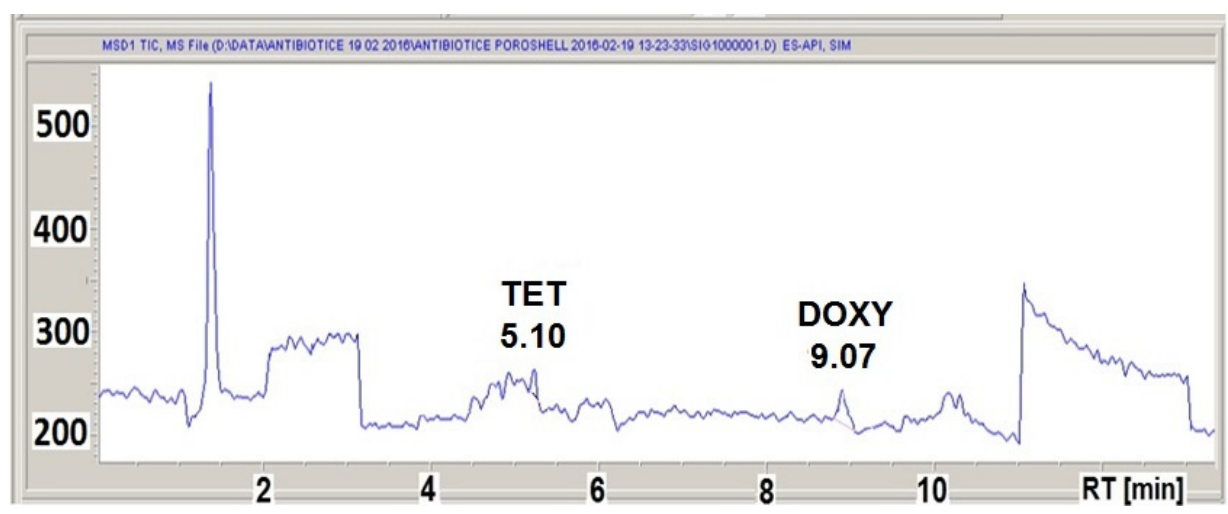

Figure 4. SIM chromatogram of a river water extract from Vișeu River, Sampling point (1), July 2015

Regarding the sediment samples, the results showed the presence of Tetracycline in the range of 143.9 and $248.8 \mu \mathrm{g} / \mathrm{kg}$ and of Doxycycline in the range of 14.6 and $27.9 \mu \mathrm{g} / \mathrm{kg}$ (Table 6 ). These results are quite logical taking into account that these two antibiotics are the most prevalent in river water samples.

Table 6. Antibiotics found in sediment extracts from Tisza River Watershed by USAE-SPE-HPLC-DAD procedure

\begin{tabular}{|l|ll|l|}
\hline Sampling date & \multicolumn{2}{|l|}{ Sampling point } & Antibiotics found and their amounts $[\mu \mathrm{g} / \mathrm{Kg}]$ \\
\hline \multirow{3}{*}{ July 2015} & Vișeu & $(1)$ & Tetracycline (143.9) \\
\cline { 2 - 4 } & Iza & $(2)$ & Tetracycline (156.8), Doxycycline (27.9) \\
\cline { 2 - 4 } & Tisza & $(3)$ & Tetracycline (248.8), Doxycycline (14.6) \\
\hline
\end{tabular}

\section{CONCLUSIONS}

Two analytical procedures, SPE-HPLC-DAD and SPE-LC-ESI(+)MS, have been developed in order to determine some antibiotics in river water samples collected from the Romanian Tisza River Watershed (Vișeu, Iza and Tisza Rivers). 
The developed procedures show good linearity and limits of detection and quantification, being applicable to the analysis of the selected antibiotics in real river water samples. SPE-LC-ESI(+)-MS is more suitable for the analysis of antibiotics in surface waters being more sensitive than HPLC-DAD.

The SPE-LC-ESI(+)-MS procedure has been applied to monitor the target antibiotics in river water samples collected during 13 months. The most found antibiotics were Tetracycline $(0.10-5.24 \mu \mathrm{g} / \mathrm{L})$, Doxycycline $(0.11-2.46 \mu \mathrm{g} / \mathrm{L})$ and Ceftazidime $(0.01-4.20 \mu \mathrm{g} / \mathrm{L})$. Also, Penicillin $\mathrm{G}$ was found two times (3.41 and $4.67 \mu \mathrm{g} / \mathrm{L}$ ).

For the sediment samples, the USAE-SPE-HPLC-DAD procedure has been developed, based on the previous SPE-HPLC-DAD procedure.

In the analysed sediments, Tetracycline and Doxycycline in concentration of hundred, respectively tens $\mu \mathrm{g} / \mathrm{kg}$ were found.

The presence of antibiotics in river waters is a growing environmental problem, therefore the periodical monitoring is recommended.

\section{EXPERIMENTAL SECTION}

\section{Chemicals and materials}

For the optimization of the extraction protocols and of the qualitative and quantitative analysis, a standard mixture containing the six selected antibiotics (Figure 5) was prepared. The considered antibiotic standards were commercial powders used for oral treatment (Amoxicillin trihydrate $500 \mathrm{mg}$ per capsule with talcum and magnesium stearate as excipients, Tetracycline chlorhydrate $250 \mathrm{mg}$ per capsule with lactose and magnesium stearate as excipients, and Doxycycline $100 \mathrm{mg}$ per capsule as hyclate $119 \mathrm{mg}$ with corn starch, magnesium stearate and talcum as excipients) or for injection (Ampicillin natrium salt $1 \mathrm{~g}$ per vial, Penicillin G potassium salt 1.000.000 U.I. per vial, and Ceftazidime $1 \mathrm{~g}$ per vial). The antibiotics were purchased from "Antibiotice" Romania (Amoxicillin, Ampicillin, Penicillin G, Tetracycline), "GlaxoSmithKline" Romania (Ceftazidime) and "Sandoz" Romania (Doxycycline).

Standard solutions in the concentration range of 0.65 to $166.7 \mathrm{ng} / \mathrm{mL}$ prepared by the dilution of standard mixture in Milli-Q water were used for calibration. Methanol and acetonitrile of HPLC grade purity and formic acid of $99.9 \%$ purity were purchased from Merck (Germany). The Milli-Q water was prepared using a Milli-Q Plus water system from Millipore (USA). Before injection, the samples were passed through Teknokroma syringe filters, PTFE $0.45 \mu \mathrm{m}$. 
<smiles>CC1(C)S[C@H]2[C@H](NC(=O)[C@@H](N)c3ccc(O)cc3)C(=O)N2C1C(=O)O</smiles>

Amoxicillin<smiles>CC1(C)S[C@@H]2[C@H](NC(=O)[C@@H](N)c3ccccc3)C(=O)N2[C@H]1C(=O)O[Na]</smiles>

Penicillin G<smiles>CN(C)C1C(O)=C(C(N)=O)C(=O)[C@]2(O)C(O)=C3C(=O)c4c(O)cccc4[C@@](C)(O)[C@H]3C[C@H]12</smiles>

Tetracycline<smiles>CC1(C)S[C@@H]2C(NC(=O)C(N)c3ccccc3)C(=O)N2C1C(=O)O[Na]</smiles>

Ampicillin<smiles>CC(C)(O/N=C(/C(=O)N[C@@H]1C(=O)N2C(C(=O)[O-])=C(C[n+]3ccccc3)CS[C@H]12)c1csc(N)n1)C(=O)O</smiles>

Ceftazidime<smiles>C[C@H]1c2cccc(O)c2C(=O)C2=C(O)[C@]3(O)C(=O)C(C(N)=O)=C(O)[C@@H](N(C)C)[C@H]3[C@H](O)[C@H]21</smiles>

Doxycycline

Figure 5. Structure formula of the studied antibiotics

\section{Instrumentation and chromatographic separation}

For the chromatographic analyses, an HPLC Agilent 1200 Series system, equipped with G1322A degasser, G1311A quaternary pump, G1329A autosampler, G1315D DAD detector, and G1316B TCC SL column thermostat and a LC-MS system model Agilent 1200 Series coupled with 6110 Quadrupole LC/MS detector with AP-ESI ionization were used. The chromatographic data were collected and processed by means of the ChemStation software.

The separation was carried out on Agilent Poroshell 120 EC-C18 column $(4.6 \times 150 \mathrm{~mm}, 2.7 \mu \mathrm{m})$ at a flow rate of $1.1 \mathrm{~mL} / \mathrm{min}$ using a mobile phase consisting in a mixture of $(A)$ acetonitrile and (B) $0.1 \%$ formic acid in water $(v / v)$ operated under the following gradient (Table 7): 
Table 7. Gradient elution used for the separation of target antibiotics

\begin{tabular}{|c|c|c|}
\hline \multirow{2}{*}{ Time $[\mathrm{min}]$} & \multicolumn{2}{|c|}{ Mobile phase composition [\%] } \\
\cline { 2 - 3 } & A: (Acetonitrile) & B: $(0.1 \%$ formic acid in water) \\
\hline 0 & 10 & 90 \\
\hline 3 & 20 & 80 \\
\hline 6 & 20 & 80 \\
\hline 8 & 40 & 60 \\
\hline 10 & 10 & 90 \\
\hline 13 & \multicolumn{2}{|c|}{ STOP elution } \\
\hline
\end{tabular}

The column temperature was fixed at $35^{\circ} \mathrm{C}$. A volume of $20 \mu \mathrm{L}$ sample was injected for the DAD detection and one of $1.0 \mu \mathrm{L}$ for the MS detection respectively.

For the DAD detection, two wavelengths were used, one of $197 \mathrm{~nm}$ for penicillins and another one of $272 \mathrm{~nm}$ for tetracyclines and cephalosporins. MS was operated in SIM mode using positive electrospray ionization (ESI $(+))$.

\section{Samples collection and extraction conditions}

The present study was performed in the Romanian Tisza River Watershed. Two monitoring points were selected on the main tributaries (Vişeu and Iza Rivers) and one on the Tisza River. The first sampling point was located at Vişeu Valley village, near the confluence of Vişeu River with Tisza River, the second one at Sighetu Marmaţiei town where Iza River flows into Tisza River and the third one at Teceu Mic village where Tisza River leaves the Romanian territory (Figure 6).

Monitoring in Tisza River Watershed was conducted over the course of 13 months, from July 2014 to September 2015. During this period, water river samples were collected using a manual water sample device and kept in a brown glass bottle at $5^{\circ} \mathrm{C}$ before analyses.

Sediment samples were collected in July 2015 using a stainless steel grab sampler and were kept in glass jars at $5^{\circ} \mathrm{C}$ before analysis.

Isolation of the target antibiotics from the water samples was done by solid-phase extraction while from the sediment samples by ultrasoundassisted extraction followed by solid-phase extraction (USAE-SPE). 


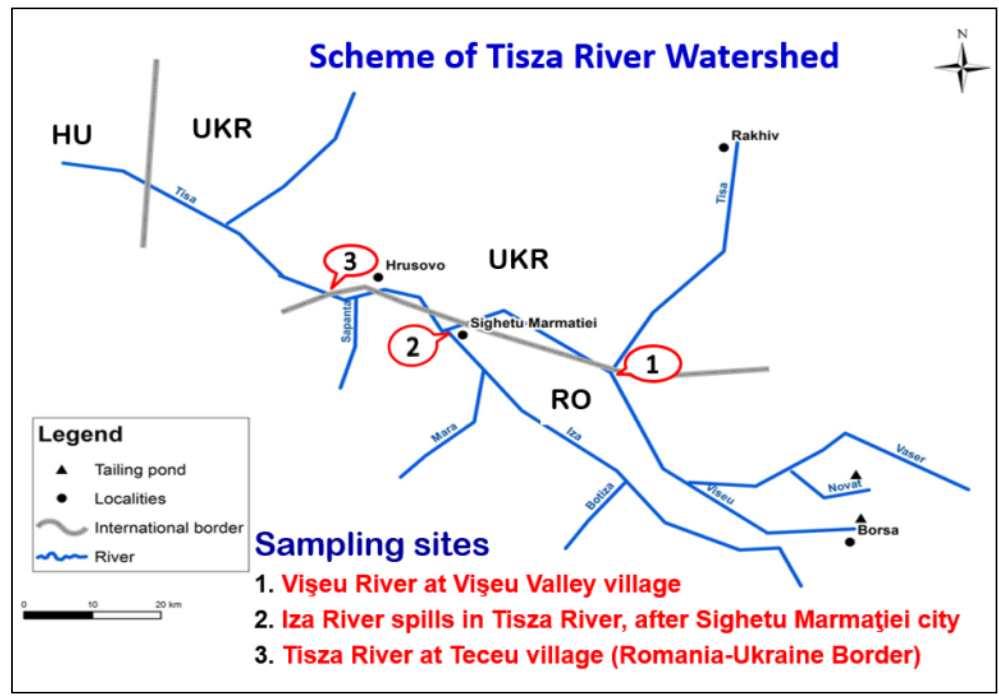

Figure 6. The three monitoring points selected for study

OASIS HLB cartridges ( $500 \mathrm{mg} / 6 \mathrm{~mL}$ ) were used for the extraction of antibiotics from water samples. Before extraction, the cartridges were conditioned by washing with $5 \mathrm{~mL}$ methanol and then with $5 \mathrm{~mL}$ Milli-Q water. The sorbent was equilibrated by washing with $5 \mathrm{~mL}$ solution of $5 \%$ methanol in Milli-Q water.

For SPE, a volume of $400 \mathrm{~mL}$ river water sample was passed through cartridges at a flow rate of $5 \mathrm{~mL} / \mathrm{min}$, subsequent by the elution of retained antibiotics with $5 \mathrm{~mL}$ methanol+acetonitrile $(1: 1, \mathrm{v} / \mathrm{v})$ mixture. After evaporation to dryness under nitrogen, the residue was dissolved in $1 \mathrm{~mL}$ acetonitrile and subjected to the HPLC analysis.

For the extraction of antibiotics from sediment samples, $3 \mathrm{~g}$ of dried sediment (room temperature) was extracted with $20 \mathrm{~mL}$ methanol in an ultrasonic bath for 30 minutes. After centrifugation at 4000 rpm for 15 minutes, the supernatant was collected and evaporated to dryness under nitrogen. The residue was reconstituted in $100 \mathrm{~mL}$ distilled water and subjected to the SPE extraction under the procedure used for the river water samples.

\section{ACKNOWLEDGMENTS}

This work was conducted within the NATO Science for Peace 984440/ 2014-2017 Project. 


\section{REFERENCES}

1. K. Kümmerer, Chemosphere, 2009, 75, 417.

2. J.L. Martinez, Environmental Pollution, 2009, 157, 2893.

3. S. Manzetti, R. Ghisi, Marine Pollution Bulletin, 2014, 79, 7.

4. X. Chang, M.T. Meyer, X. Liu, Q. Zhao, H. Chen, J. Chen, Z. Qiu, L. Yang, J. Cao, W. Shu, Environmental Pollution, 2010, 158, 1444.

5. B. Li, T. Zhang, Z. Xu, H.P. Fang, Analytica Chimica Acta, 2009, 645, 64.

6. O. Opriș, V. Coman, F. Copaciu, M. Vlassa, Journal of Planar Chromatography, 2012, 25(6), 516.

7. C. Marx, V. Mühlbauer, P. Krebs, V. Kuehn, Science of the Total Environment, 2015, 524-525, 269.

8. W.H. Xu, G. Zhang, S.C. Zou, X.D. Li, Y.C. Liu, Environmental Pollution, 2007, 145, 672.

9. O. Opriş, M.L. Soran, V. Coman, F. Copaciu, D. Ristoiu, Central European Journal of Chemistry, 2013, 11(8) 1343.

10. X. Liang, B. Chen, X. Nie, Z. Shi, X. Huang, X. Li, Chemosphere, 2013, 92(11), 1410.

11. H. Shi, Y. Yang, M. Liu, C. Yan, H. Yue, J. Zhou, Marine Pollution Bulletin, 2014, 83, 317.

12. D. Cheng, X. Liu, L. Wang, W. Gong, G. Liu, W. Fu, M. Cheng, Science of the Total Environment, 2014, 476-477, 266.

13. J. Xu, Y. Zhang, C. Zhou, C. Guo, D. Wang, P. Du, Y. Luo, J. Wan, W. Meng, Science of the Total Environment, 2014, 497-498, 267.

14. S. Zhao, X. Liu, D. Cheng, G. Liu, B. Liang, B. Cui, J. Bai, Science of the Total Environment, 2016, 569-570, 1350.

15. L. Yao, Y. Wang, L. Tong, Y. Deng, Y. Li, Y. Gan, W. Guo, C. Donga, Y. Duana, K. Zhaoa, Ecotoxicology and Environmental Safety, 2017, 135, 236.

16. B. Suárez, B. Santos, B.M. Simonet, S. Cárdenas, M. Valcárcel, Journal of Chromatography A, 2007, 1175(1) 127.

17. M.I. Bailón-Pérez, A.M. García-Campaña, C. Cruces-Blanco, M. del Olmo Iruela, Journal of Chromatography A, 2008, 1185(2), 273.

18. A.V. Herrera-Herrera, J. Hernández-Borges, T.M. Borges-Miquel, M.Á. RodríguezDelgado, Journal of Pharmaceutical and Biomedical Analysis, 2013, 75, 130.

19. Y. Li, Q. Li, K. Zhou, X.-L. Sun, L.-R. Zhao, Y.-B. Zhang, Chemosphere, 2016, $147,25$.

20. P. Bottoni, S. Caroli, Journal of Pharmaceutical and Biomedical Analysis, 2015, $106,3$. 